\title{
Recycling of Cerium and Lanthanum from Glass Polishing Sludge
}

\author{
Ching-Hwa Lee ${ }^{1}$, Yu-Chien Lo ${ }^{1}$, Nyamdorj Sandagdorj ${ }^{1 *}$, Enkhsaikhan Gankhuyag ${ }^{1}$, \\ Srinivasa Rao Popuri' ${ }^{2}$, Chi-En Hung ${ }^{1}$ \\ ${ }^{1}$ Da-Yeh University, Department of Environmental Engineering, Changhua, Taiwan, 515 R.O.C. \\ ${ }^{2}$ The University of the West Indies, Department of Biological and Chemical Sciences, Cave Hill Campus, Barbados-1100 \\ "Corresponding author: e-mail: d0505652@cloud.dyu.edu.tw
}

\begin{abstract}
To examine the efficiency of $\mathrm{La}$ and $\mathrm{Ce}$ recycling processes from the sludge, two major methods were used, namely leaching and precipitation. The findings suggest that $12 \%$ of $\mathrm{La}$ and $24.2 \%$ of Ce were contained in the sludge. The sludge was leached in an optimum condition of $6 \mathrm{~N} \mathrm{HCl}$ at a temperature of $70^{\circ} \mathrm{C}$ with a $3 \mathrm{~g} / 50 \mathrm{~mL}$ solid/ liquid ratio for $3 \mathrm{~h}$ to obtain a $100 \%$ leaching recovery of $\mathrm{La}$ and $\mathrm{Ce}$. After $\mathrm{pH}$ adjustment of the obtained $\mathrm{La}$ and $\mathrm{Ce}$ optimum leaching solution to 6 with $\mathrm{NH}_{4} \mathrm{OH}$ and a simultaneous addition of $\mathrm{H}_{2} \mathrm{O}_{2}$ in a ratio of 1:1, Ce precipitated out with $65.9 \%$ recovery. On the other hand, La was not precipitated. The results obtained in this study reveal that leaching and $\mathrm{pH}$ adjustment method could be used to recover the valuable $\mathrm{REE}$ of $\mathrm{La}$ and $\mathrm{Ce}$ from glass polishing sludge in order to reach the goals of resource recycling.
\end{abstract}

Keywords: Cerium, Lanthanum, Waste, Sludge, Leaching, Recycling.

\section{INTRODUCTION}

Rare earth elements (REE), such as cerium (Ce) and lanthanum $(\mathrm{La})$ are the main components of glass polishing powder materials. These elements are used for a broad range of polishing work, especially for glass parts of hard disk drives (HDD), high refractive index glass, camera lenses and photomasks. During the production process, the glass polishing powder does not produce any waste; but after an unsuccessful use, every ton polishing powder used will produce about 3 tons of solid waste ${ }^{1}$. Most of the wastes are discarded with wastewater sludge without further exploitation ${ }^{2}$. To preserve REEs, it is therefore necessary to investigate REE recovery from glass polishing sludge, even though most wastes are presently buried in landfills because it is not easy to treat them chemically or physically ${ }^{2}$. Although Taiwan does not have any REE resources, the country can boast an effective sludge glass polishing management system that helps increase the recycling of REE resources to some extent. Thus, the purpose of this research is to assess the recovery of $\mathrm{La}$ and $\mathrm{Ce}$ from glass polishing sludge.

Prior research was focused on recovery of REEs from various kinds of waste, such as waste phosphor and $\mathrm{NdFeB}$ magnet ${ }^{3-6}$. Recovery of these REEs is done by leaching followed by several purification processes. The amount of recovery using these methods is generally between $80 \%$ and $90 \%^{7-8}$. Leaching is a widely used hydrometallurgical technique which converts metals into soluble salt in aqueous media. Compared to pyro-metallurgical operations, leaching is less expensive and offers more flexibility in terms of establishment and operation. Acid leaching is a common industrial practice for the recovery of metals from mineral ores. The most common acids used for leaching recovery of REEs are hydrochloric acid $(\mathrm{HCl})$, sulfuric acid $\left(\mathrm{H}_{2} \mathrm{SO}_{4}\right)$, and nitric acid $\left(\mathrm{HNO}_{3}\right)^{9-13}$. Precipitation is also a commonly used method to remove metal ions from solutions. The precipitation process usually starts by $\mathrm{pH}$ adjustment, precipitation stimulation with chemicals and heat, conversion of metal ions into metal hydroxides or insoluble metal salts. $\mathrm{La}$ and $\mathrm{Ce}$ can be recovered from leaching solution by precipitation as oxalate ${ }^{10}$. Some researchers used the precipitation method to separate $\mathrm{La}$ and $\mathrm{Ce}$ from the concentrates with the aid of ammonium carbonate ${ }^{14-16}$. Khawassek ${ }^{17}$ utilized $\mathrm{HCl}$ as a precursor to precipitate $\mathrm{RE}$ carbonates. Several researchers have successfully used urea to precipitate REE into its carbonates ${ }^{18-20}$. Kim $^{21}$ for instance recovered $94 \%$ of Ce from glass polishing slurry using an oxidative, thermal treatment and subsequent chemical leaching. However, this process appeared to be expensi$\mathrm{ve}^{21}$. The dominating oxidation state of $\mathrm{La}$ and $\mathrm{Ce}$ is due to a small difference in ionic radii; hence the relative difficulty in separating these REEs ${ }^{22}$. According to Qi's research $^{22}$, the common methods used for separating La and $\mathrm{Ce}$ are crystallization, precipitation, $\mathrm{pH}$ adjustment, replacement, oxidation, and reduction ${ }^{23}$. Crystallization and precipitation are slow and tedious methods whilst the leaching reagent extraction and replacement are much more effective methods for REEs separation ${ }^{22}$.

In this research, the REEs of $\mathrm{La}$ and $\mathrm{Ce}$ are recovered from glass polishing sludge not only by using various leaching reagents such as $\mathrm{H}_{2} \mathrm{SO}_{4}, \mathrm{HNO}_{3}, \mathrm{NaOH}$, and $\mathrm{HCl}$, but also through utilization of the best leaching agent. Furthermore, batch experiments were conducted to optimize leaching conditions: solid/liquid ratio, leaching time, the concentration of the leaching reagent and leaching temperature. The optimum leaching solution containing $\mathrm{La}$ and $\mathrm{Ce}$ was subjected to precipitation ( $\mathrm{pH}$ adjustment) in order to recover the $\mathrm{La}$ and $\mathrm{Ce}$. The goal was to use a simple precipitation method with varying $\mathrm{pH}$ trends to separate and recover pure Ce by leaving $\mathrm{La}$ as an un-precipitated state in the optimal leaching solution obtained from glass polishing sludge.

\section{MATERIALS AND METHODS}

\section{Sample collection and chemicals}

The glass polishing sludge used in this research was collected from local manufacturers in Taiwan. The chemicals used were the following: $\mathrm{H}_{2} \mathrm{SO}_{4}(95 \%$, guaranteed reagent (GR) grade), $\mathrm{HNO}_{3}(65 \%$, GR grade), $\mathrm{HCl}$ (37\%, GR grade), and sodium hydroxide $(\mathrm{NaOH})$ as 
leaching reagents from Merck (a global and research-intensive biopharmaceutical company). All experiments were conducted with de-ionized water (DI-water).

\section{Composition analysis}

The parameters such as water content, ash content, density and metal concentration were analyzed with $<100$ mesh $(0.149 \mathrm{~mm})$-screened glass polishing sludge samples. Water content, ash content and density of ground samples were analyzed using two industrial wastewater measurement methods of the Taiwan Environmental Protection Administration (EPAT); these two measurement methods are NIEA R203.02 $\mathrm{C}^{24}$ and NIEA R205.01C ${ }^{25}$. The method used for determining the metal concentrations was the TEPA's established heavy metal digestion method known as NIEA S321.64B $\mathrm{B}^{26}$. The experiment involved a series of steps: $3 \mathrm{~g}$ of glass polishing sludge mixed with a $250 \mathrm{~mL}$ reactor containing $1 \mathrm{~mL}$ DI-water for wetting the sample. To this solution mixture, were gradually added $21 \mathrm{~mL} \mathrm{HCl}$ and $7 \mathrm{~mL} \mathrm{HNO}_{3}$ solutions allowed to react for $16 \mathrm{~h}$ at $27^{\circ} \mathrm{C}$. The reaction temperature was also increased gradually, and the solution was boiled for $2 \mathrm{~h}$. After the reaction temperature was cooled, $10 \mathrm{~mL}$ of a $0.3 \mathrm{~N} \mathrm{HNO}_{3}$ solution was used to wash the condenser and then added to the reactor. The REE concentration of $\mathrm{La}$ and $\mathrm{Ce}$ were analyzed using inductively coupled plasma-atomic emission spectrometry (ICP-AES).

\section{Leaching}

Leaching experiments were conducted with $\mathrm{HNO}_{3}$, $\mathrm{HCl}, \mathrm{H}_{2} \mathrm{SO}_{4}$ and $\mathrm{NaOH}$ to determine the level of $\mathrm{La}$ and Ce present in the glass powder samples and to optimize the leaching conditions of reaction time, concentration of leaching reagent, solid/liquid ratio, and temperature. For each experiment, $50 \mathrm{~mL}$ of leaching reagent was used with an agitation speed of $150 \mathrm{rpm}$ on a heating magnetic stirrer. The percentage of leaching recovery was calculated using Equation (1).

Leaching recovery $(\%)=\frac{W_{1}}{W_{2}} \times 100 \%$;

where $w_{1}$ is the weight of metal leached, and $w_{2}$ is the weight of metal contained in the sample.

\section{Precipitation}

To separate $\mathrm{La}$ and $\mathrm{Ce}$ from the optimal $\mathrm{HCl}$ leaching solution, a hydrometallurgical precipitation method with varying $\mathrm{pH}$ levels was adopted. The results obtained at various time intervals of precipitation were analyzed by using ICP-AES ${ }^{27}$. Precipitation recovery of La and Ce at various $\mathrm{pH}$ values were calculated based on Equation (5), and the solubility response equation is as shown in Equation (2, 3 and 4$)^{28}$.

$\mathrm{Ce}^{+4}+\mathrm{OH}^{-} \rightarrow \mathrm{Ce}(\mathrm{OH})_{4} \mathrm{Ksp}=4 \times 10^{-49}$

$\mathrm{Ce}^{+3}+\mathrm{OH}^{-} \rightarrow \mathrm{Ce}(\mathrm{OH})_{3} \quad \mathrm{Ksp}=1.5 \times 10^{-20}$

$\mathrm{La}^{+3}+\mathrm{OH}^{-} \rightarrow \mathrm{La}(\mathrm{OH})_{3} \quad \mathrm{Ksp}=1.0 \times 10^{-19}$

Precipitation recovery $(\%)=\frac{W_{b}-W_{c}}{W_{b}} \times 100 \%$;

where $\mathrm{w}_{\mathrm{b}}$ is the weight of metal in solution before precipitation and $\mathrm{w}_{\mathrm{a}}$ is the weight of metal in solution after precipitation.

\section{RESULTS AND DISCUSSION}

\section{Sample composition analysis}

The collected glass polishing sludge had a size of $<0.149 \mathrm{~mm}$ and the amount of $\mathrm{La}$ and Ce present were $12 \%$ and $24.2 \%$, respectively. Water content, ash content, combustible material and specific gravity of these ground samples were also analyzed, and the results were respectively $7.23 \%, 27.61 \%, 65.16 \%$, and $2.65 \mathrm{~g} / \mathrm{cm}^{3}$.

\section{Leaching}

In order to recover the $\mathrm{La}$ and $\mathrm{Ce}$ from glass polishing sludge, and to examine the optimum leaching conditions for the target metal dissolution, the leaching experiments were conducted with four reagents, namely $\mathrm{HNO}_{3}, \mathrm{HCl}$, $\mathrm{H}_{2} \mathrm{SO}_{4}$, and $\mathrm{NaOH}$ at various experimental conditions. The results are presented in Figures. 1, 2, and 3. Figure. 1 shows the effect of leaching reaction time on recovery of $\mathrm{La}$ and $\mathrm{Ce}$ at $70^{\circ} \mathrm{C}$, the concentration of leaching reagent $1 \mathrm{~N}$ and the solid/liquid ratio of $1 \mathrm{~g} / 50 \mathrm{~mL}$. The result in Figure. 1 indicates that with an increase in the reaction time from 0.5 to $3 \mathrm{~h}$, the leaching recovery of $\mathrm{La}$ and Ce for $\mathrm{HNO}_{3}, \mathrm{HCl}$, and $\mathrm{H}_{2} \mathrm{SO}_{4}$ also increased. However, the recovery of $\mathrm{La}$ and $\mathrm{Ce}$ with $\mathrm{NaOH}$ was nearly $0 \%$ and therefore, considered as ineffective. Figure. 1 also reveals that the leaching recovery of La was higher than the recovery of Ce with $\mathrm{HNO}_{3}, \mathrm{HCl}$, and $\mathrm{H}_{2} \mathrm{SO}_{4}$ reagents. For example, we obtained $67.59 \%$ recovery of $\mathrm{La}$ and $1.85 \%$ recovery of $\mathrm{Ce}$ with $1 \mathrm{~N} \mathrm{HCl}$ under the same experimental conditions. Leaching recovery of $\mathrm{La}$

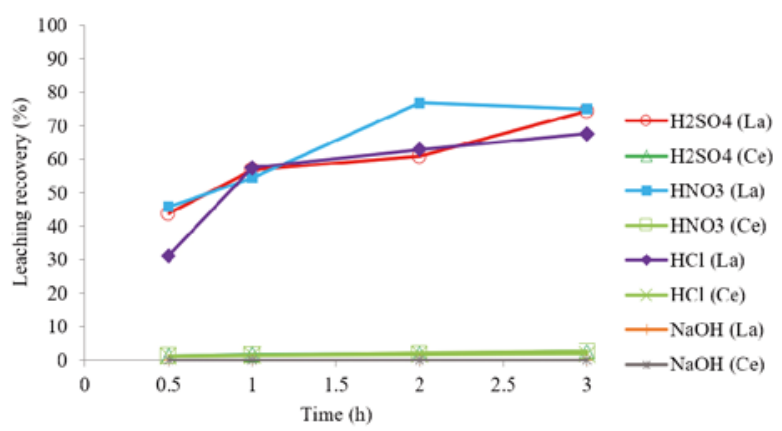

Figure 1. Effect of time on leaching recovery of $\mathrm{La}$ and $\mathrm{Ce}$ with $\mathrm{HCl}, \mathrm{H}_{2} \mathrm{SO}_{4}, \mathrm{HNO}_{3}$ and $\mathrm{NaOH}$ from glass polishing sludge (concentration of leaching reagent $=1 \mathrm{~N}$, temperature $=70^{\circ} \mathrm{C}$, solid/liquid ratio $=$ $1 \mathrm{~g} / 50 \mathrm{~mL}$ )

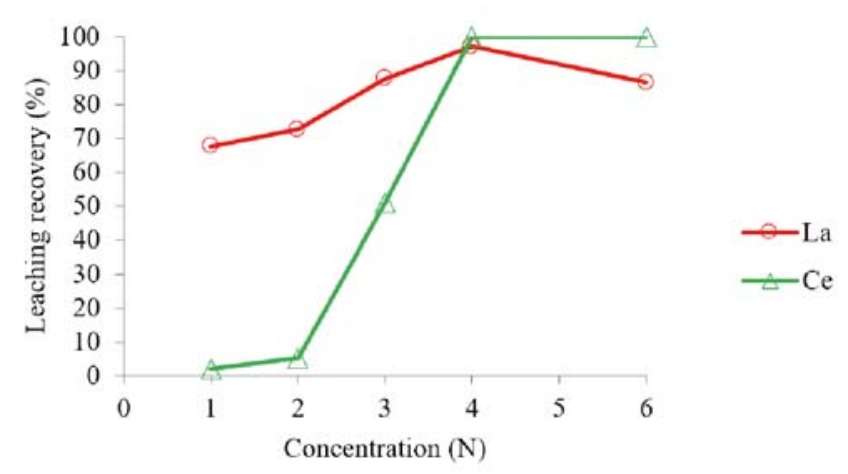

Figure 2. Effect of $\mathrm{HCl}$ leaching reagent concentration on leaching recovery of $\mathrm{La}$ and $\mathrm{Ce}$ (leaching time $=3 \mathrm{~h}$, temperature $=70^{\circ} \mathrm{C}$, solid/liquid ratio $=1 \mathrm{~g} / 50 \mathrm{~mL}$ ) 


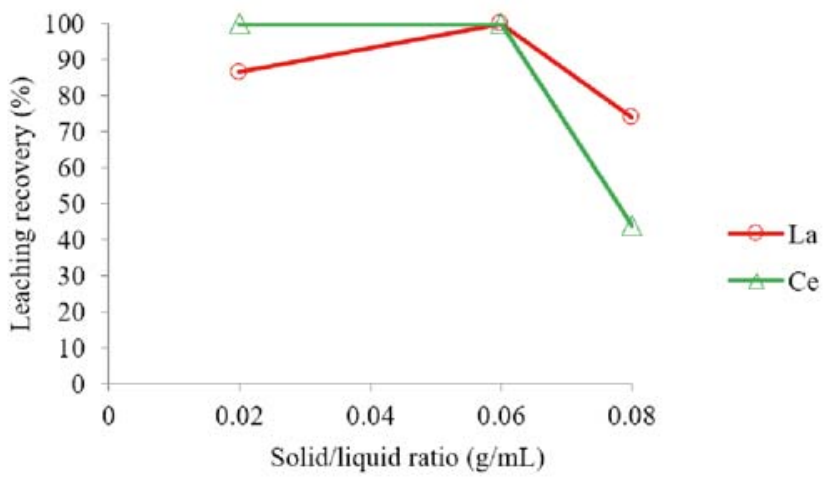

Figure 3. Effect of solid/liquid ratio on the leaching recovery of $\mathrm{La}$ and Ce with $6 \mathrm{~N} \mathrm{HCl}$ (Leaching time $=3 \mathrm{~h}$, temperature $=70^{\circ} \mathrm{C}$ )

and $\mathrm{Ce}$ also amounted to $74.96 \%$ and $2.67 \%$ (with $1 \mathrm{~N}$ $\mathrm{HNO}_{3}$ ), and $74.38 \%$ and $2.54 \%$ (with $1 \mathrm{~N} \mathrm{H}_{2} \mathrm{SO}_{4}$ ).

Figure. 2 shows the leaching recovery percentage of $\mathrm{La}$ and $\mathrm{Ce}$ with varying $\mathrm{HCl}$ concentration levels from $1 \mathrm{~N}$ to $6 \mathrm{~N}$ at a reaction time of $3 \mathrm{~h}$, a temperature of $70^{\circ} \mathrm{C}$ and a solid/liquid ratio of $1 \mathrm{~g} / 50 \mathrm{~mL}$. Therefore, further leaching experiments were conducted with $\mathrm{HCl}$ for the recovery of $\mathrm{La}$ and $\mathrm{Ce}$ in order to find the optimum conditions, such as leaching time, leaching temperature, and solid/liquid ratio.

The effect of quantity on glass polishing sludge in $50 \mathrm{~mL}$ of leaching solution on the recovery efficiency of $\mathrm{La}$ and $\mathrm{Ce}$ was found by using the solid/liquid ratio $1 \mathrm{~g} / 50 \mathrm{~mL}$ (0.02), $3 \mathrm{~g} / 50 \mathrm{~mL}(0.06)$, and $4 \mathrm{~g} / 50 \mathrm{~mL}$ (0.08) with $6 \mathrm{~N}$ concentration of $\mathrm{HCl}$ solution, and $3 \mathrm{~h}$ of contact time at $70^{\circ} \mathrm{C}$. The leaching of different solid/liquid ratios and recovery rates are presented in Figure. 3. Results showed that the leaching recovery of La and Ce present in glass polishing sludge was high for solid/liquid ratio from $1 \mathrm{~g} / 50 \mathrm{~mL}$ to $3 \mathrm{~g} / 50 \mathrm{~mL}$ and decreased afterwards. The results also indicated that the leaching recovery of La and Ce present in glass polishing sludge was $100 \%$ at a solid/liquid ratio of $3 \mathrm{~g} / 50 \mathrm{~mL}$ by using a $6 \mathrm{~N} \mathrm{HCl}$ leaching acid. Thus, the optimum leaching conditions finalized in this study were $\mathrm{HCl}$ as a leaching reagent with $6 \mathrm{~N}$ concentration, $3 \mathrm{~h}$ of leaching time, a $3 \mathrm{~g} / 50 \mathrm{~mL}$ solid/liquid ratio, and a temperature of $70^{\circ} \mathrm{C}$. The implication is that an optimum leaching solution with a $100 \%$ leaching recovery of $\mathrm{La}$ and $\mathrm{Ce}$ can be obtained by using optimum leaching conditions.

\section{Precipitation}

The La and Ce leached in the optimum solution can be converted into metal precipitate by changing the solution's $\mathrm{pH}$ value. Since the leaching was conducted with $\mathrm{HCl}$, the $\mathrm{pH}$ of the solution was adjusted by ammonium hydroxide $\left(\mathrm{NH}_{4} \mathrm{OH}\right)$ and $\mathrm{NaOH}$. At the end of each $\mathrm{pH}$ adjustment experiment, the metal concentrations of $\mathrm{La}$ and $\mathrm{Ce}$ in the solution were analyzed using ICP-AES. Then the precipitation recovery of La and Ce was calculated based on Equation (5). The obtained precipitation recovery of $\mathrm{La}$ and $\mathrm{Ce}$ of the optimum leaching solution by adding $\mathrm{NaOH}$ and $\mathrm{NH}_{4} \mathrm{OH}$ under different $\mathrm{pH}$ values are shown in Figures. 4 and 5. Result indicated that when the $\mathrm{pH}$ values were increased, the precipitation recovery also increased. Also, the $\mathrm{NH}_{4} \mathrm{OH}$ precipitation

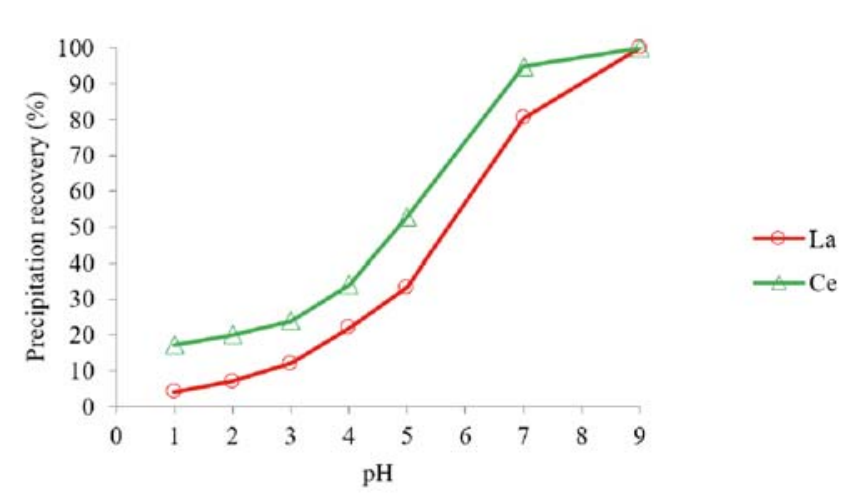

Figure 4. Precipitation recovery of $\mathrm{La}$ and $\mathrm{Ce}$ under different $\mathrm{pH}$ values by using $\mathrm{NH}_{4} \mathrm{OH}$

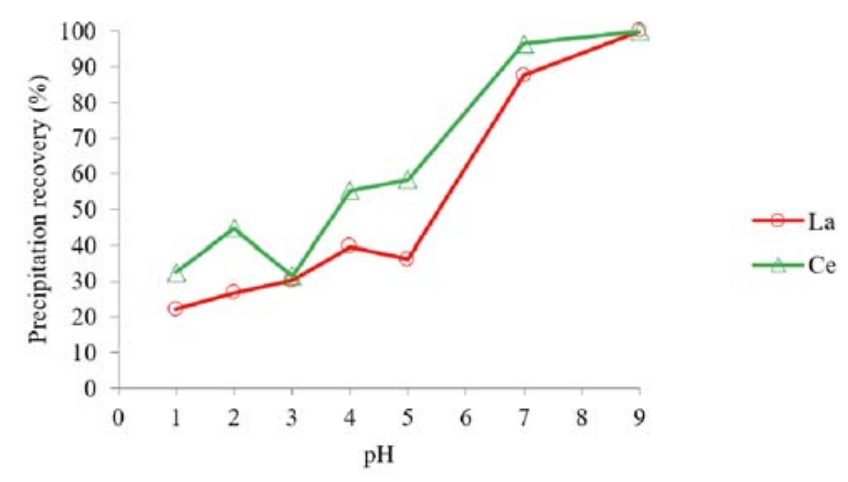

Figure 5. Precipitation recovery of $\mathrm{La}$ and $\mathrm{Ce}$ under different $\mathrm{pH}$ values by using $\mathrm{NaOH}$

recovery of $\mathrm{La}$ and $\mathrm{Ce}$ were better than $\mathrm{NaOH}$, as the recovery of $\mathrm{La}$ and $\mathrm{Ce}$ at $\mathrm{pH} 9$ were $99.99 \%$ and $100 \%$, respectively. However, both $\mathrm{pH}$ adjustments by using $\mathrm{NaOH}$ and $\mathrm{NH}_{4} \mathrm{OH}$ couldn't help achieve the separation of $\mathrm{La}$ and $\mathrm{Ce}$.

In order to achieve the separation of $\mathrm{Ce}$ and $\mathrm{La}$, the optimum leaching solution was adjusted over the range of 0.5-9 with ammonia water and simultaneous addition of hydrogen peroxide $\left(\mathrm{H}_{2} \mathrm{O}_{2}\right)$ with a concentration of $30 \%$ in a ratio of 1:1. The precipitation recovery of $\mathrm{La}$ and Ce of the $\mathrm{pH}$ adjustment experiments mentioned above is illustrated in Figure. 6. The precipitation recovery of Ce increased from $32.99 \%$ to $99.99 \%$ with increasing $\mathrm{pH}$ values from 0.5 to 9 .

However, precipitation recovery of La decreased from $23.53 \%$ to $0 \%$ with increasing $\mathrm{pH}$ values from 0.5 to 5 and followed the same trend up to $\mathrm{pH}$ 6. Then La in-

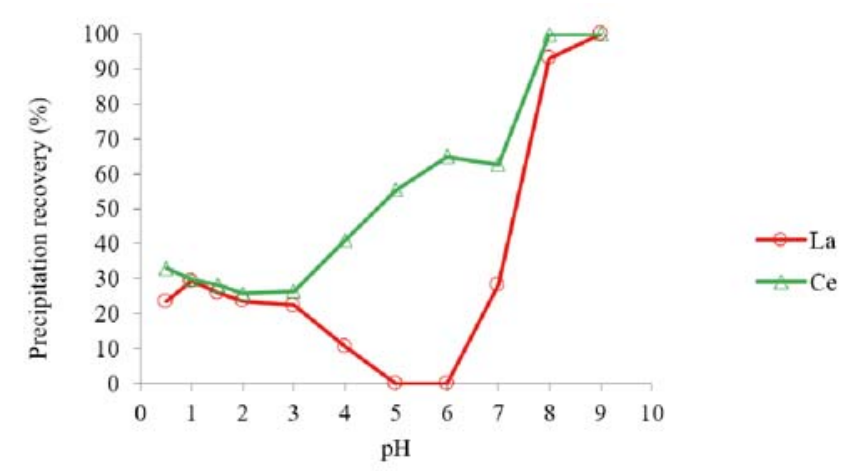

Figure 6. Precipitation recovery of $\mathrm{La}$ and $\mathrm{Ce}$ under different $\mathrm{pH}$ values by using $\mathrm{NH}_{4} \mathrm{OH}$ with an $\mathrm{H}_{2} \mathrm{O}_{2}$ /solution volume ratio of 1 
creased from $28.18 \%$ to $100 \%$ with increasing $\mathrm{pH}$ values from 7 to 9 . Ce was successfully separated with $65.9 \%$ through precipitation by adjusting $\mathrm{pH}$ from optimum $\mathrm{HCl}$ leaching solution, whilst La was not separated.

Therefore, precipitation with a $\mathrm{pH}$ adjustment method by adding $\mathrm{NH}_{4} \mathrm{OH}$ and $\mathrm{H}_{2} \mathrm{O}_{2}$ was the best option for the separation of $\mathrm{La}$ and $\mathrm{Ce}$. The precipitation recovery of $\mathrm{La}$ and $\mathrm{Ce}$ under different $\mathrm{H}_{2} \mathrm{O}_{2}$ solution volume ratios at pH6 is shown in Figure. 7. It clearly shows that the best separation of Ce and La is under the $\mathrm{H}_{2} \mathrm{O}_{2}$ /solution volume ratio of $1: 1$ by using $\mathrm{NH}_{4} \mathrm{OH}$ at $\mathrm{pH} 6$. This means that $65.9 \%$ of the Ce contained in the glass polish sludge can be separated and purified under this best precipitation condition.

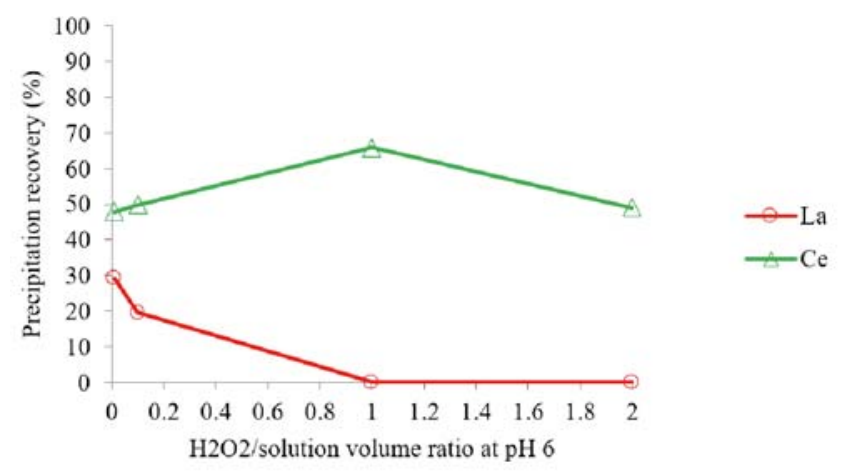

Figure 7. Precipitation recovery of La and $\mathrm{Ce}$ under different $\mathrm{H}_{2} \mathrm{O}_{2}$ /solution volume ratios at $\mathrm{pH} 6$ by $\mathrm{NH}_{4} \mathrm{OH}$

\section{CONCLUSIONS}

This paper assesses the recovery and purification process of lanthanum (La) and cerium $(\mathrm{Ce})$ from glass polishing sludge by using the hydrometallurgical method for limited rare earth elements (REE) resources conservation with the goal to help reduce waste disposal problems. The major metals contained in the glass polishing sludge were $\mathrm{La}(12 \%)$ and $\mathrm{Ce}(24.2 \%)$. Acid leaching recovery furnished the results in the range of $\mathrm{La}$ and $\mathrm{Ce}$ and the trend of leaching recovery was $\mathrm{HCl}>\mathrm{H}-$ $\mathrm{NO}_{3}>\mathrm{H}_{2} \mathrm{SO}_{4}>\mathrm{NaOH}$. The ore sample was leached in an optimum condition of $6 \mathrm{~N} \mathrm{HCl}$ at a temperature of $70^{\circ} \mathrm{C}$ and $0.06 \mathrm{~g} / \mathrm{mL}$ solid/liquid ratio for $3 \mathrm{~h}$ to obtain $100 \%$ leaching recovery of $\mathrm{La}$ and $\mathrm{Ce}$. Furthermore, $\mathrm{pH}$ adjustments recovery of $\mathrm{La}$ and $\mathrm{Ce}$ were $\mathrm{HN}_{4} \mathrm{OH}>\mathrm{Na}$ $\mathrm{OH}$. However, both $\mathrm{pH}$ adjustments by using $\mathrm{NaOH}$ and $\mathrm{NH}_{4} \mathrm{OH}$ couldn't help achieve the separation of $\mathrm{La}$ and Ce. $65.9 \%$ Ce contained in the optimum leaching solution was precipitated and purified with precipitation method by using ammonia water to adjust the solution $\mathrm{pH}$ to 6 while simultaneously adding $\mathrm{H}_{2} \mathrm{O}_{2}$ to a leaching solution volume ratio of 1:1. La, however, did not precipitate. Therefore, we conclude that leaching and precipitation with $\mathrm{pH}$ adjustment by adding $\mathrm{NH}_{4} \mathrm{OH}$ and $\mathrm{H}_{2} \mathrm{O}_{2}$ could be used to recover and purify the valuable REE of Ce from glass polishing sludge. Results obtained in this work reveal that leaching and $\mathrm{pH}$ adjustment methods could be used to recover valuable metals from glass polishing sludge in order to reach the goals of resource recycling.

\section{LITERATURE CITED}

1. Hung, C.E. (2014). Resource Recovery, Leaching Modeling, Life Cycle Assessment and Carbon Footprint of Waste Glass Polishing Powder, Unpublished doctoral dissertation, University of Da-Yeh, Changhua, Taiwan.

2. Pavel, J., Pavel, K., Jakub, E., Martin, S., Lubos, V., Martin, P., Jiri, H., Karel, M. \& Miroslaw, S. (2015). Recovery of Cerium Dioxide from Spent Glass-Polishing Slurry and Its Utilization as a Reactive Sorbent for Fast Degradation of Toxic Organophosphates. Adv. Mater. Sci. Eng. 2015, Article ID 241421. DOI: $10.1155 / 2015 / 241421$.

3. Tan, Q., Deng, C. \& Li, J. (2017). Enhanced recovery of rare earth elements from waste phosphors by mechanical activation. Cleaner. Production. 142(4), 2187-2191. DOI: 10.1016/j.jclepro.2016.11.062.

4. Padhan, E., Nayak, A.K. \& Sarangi, K. (2017). Recovery of neodymium and dysprosium from $\mathrm{NdFeB}$ magnet swarf. Hydrometallurgy. 174, 210-215. DOI: 10.1016/j.hydromet.2017.10.015.

5. Bolanz, R.M., Kiefer, S., Gottlicher, J. \& Steininger, R. (2018). Hematite $\left(\alpha-\mathrm{Fe}_{2} \mathrm{O}_{3}\right)-\mathrm{A}$ potential $\mathrm{Ce}^{4+}$ carrier in red mud. Sci. Total. Environ. 622-623, 849-860. DOI: 10.1016/j. scitotenv.2017.12.043.

6. Lee, C.H., Chang, Y.W., Popuri, S.R., Hung, C.E., Liao, C.H., Chang, J-E. \& Chen,W. (2018). Recovery of silicon, copper and aluminum from scrap silicon wafers by leaching and precipitation. Environ. Eng. Manag. J. 17(3), 561-568. DOI: 10.1177/0734242X13479433.

7. Lee, C.H., Liao, C.H., Popuri, S.R. \& Hung, C.E. (2017). Integrated process development for the recovery of Europium and Yttrium from waste fluorescent powder. Mater. Cycles. Waste. Manag. 19(3), 1235-1243. DOI: 10.1007/s10163-0160515-y.

8. Kim, R., Cho, H., Han, K.N., Kim, K., Mun, M. (2016). Optimization of Acid Leaching of Rare-Earth Elements from Mongolian Apatite-Based Ore. Minerals. 6, 63. DOI: 10.3390/ $\min 6030063$.

9. Yuan, H., Hong, W., Zhou, Y., Pu, B., Gong, A., Xu, T., Yang, Q., Li, F., Qiu, L., Zhang, W. \& Liu, Y. (2018). Extraction and back-extraction behaviors of 14 rare earth elements from sulfuric acid medium by TODGA. Rare Earths. 36(6), 642-647. DOI: 10.1016/j.jre.2018.01.011.

10. Sobianowska-Turek, A. (2018). Hydrometallurgical recovery of metals: $\mathrm{Ce}, \mathrm{La}, \mathrm{Co}, \mathrm{Fe}, \mathrm{Mn}, \mathrm{Ni}$ and $\mathrm{Zn}$ from the stream of used Ni-MH cells. Waste. Manag. 77, 213-219. DOI: 10.1016/j.wasman.2018.03.046.

11. Lee, C.H., Yen, H.Y., Liao, C.H., Popuri, S.R., Cadogan, E. \& Hsu, C.J. (2017). Hydrometallurgical processing of $\mathrm{Nd}-\mathrm{Fe}-\mathrm{B}$ magnets for $\mathrm{Nd}$ purification. J. Mater. Cycles. Waste. Manag. 19(1), 102-110. DOI: 10.1007/s10163-015-0382-y.

12. Önal, M.A.R., Aktan, E., Borra, C.R., Blanpain, B., Van Gerven, T. \& Guo, M. (2017). Recycling of NdFeB magnets using nitration, calcination and water leaching for REE recovery. Hydrometallurgy. 167, 115-123. DOI: 10.1016/j. hydromet.2016.11.006.

13. Ferdowsi, A. \& Yoozbashizaden, H. (2017). Process optimization and kinetics for leaching of cerium, lanthanum and neodymium elements from iron ore waste's apatite by nitric acid. T. Nonferr. Metal. Soc. 27(2), 420-428. DOI: 10.1016/ S1003-6326(17)60048-7.

14. de Vasconcellos, M.E., da Rocha, S.M.R., Pedreira, W.R., Queiroz, C.A.d.S. \& Abrão, A. (2008). Solubility behavior of rare earths with ammonium carbonate and ammonium carbonate plus ammonium hydroxide: Precipitation of their peroxicarbonates. J. Alloys Comp. 451, (1-2), 426-428. DOI: 10.1016/j.jallcom.2007.04.163.

15. Wang, J., Huang, X., Cui, D., Wang, L., Feng, Z., Hu, B., Long, Z. \& Zhao, N. (2017). Recovery of rare earths and aluminum from FCC waste slag by acid leaching and selective 
precipitation. J. Rare Earths. 35(11), 1141-1148. DOI: 10.1016/j. jre.2017.05.011.

16. Ozawa, M., Onoe, R. \& Kato, H. (2006). Formation and decomposition of some rare earth $(\mathrm{RE}=\mathrm{La}, \mathrm{Ce}, \mathrm{Pr})$ hydroxides and oxides by homogeneous precipitation. J. Alloys Comp. 408-412, 556-559. DOI: 10.1016/j.jallcom.2004.12.073.

17. Khawassek, Y.M., Eliwa, A.A., Gawad, E.A. \& Abdo, S.M. (2015). Recovery of rare earth elements from El-Sela effluent solutions. J. Radiat. Res. Appl. Sci. 8(4), 583-589. DOI: 10.1016/j.jrras.2015.07.002.

18. Akinc, M., Sordelet, D.J. \& Munson, M. (1988). Formation, structure, and decomposition of lanthanide basic carbonates. J. Adv. Ceram. Mat. 3(3), 211-216. DOI: 10.1111/j.15512916.1988.tb00203.x.

19. Panchula, M.L. \& Akinc, M. (1996). Morphology of lanthanum carbonate particles prepared by homogeneous precipitation. J. Eur. Ceram. Soc. 16(8), 833-841. DOI: 10.1016/0955-2219(95)00211-1.

20. Umeda, K. \& Abrao, A. (1975). Separation of individual lanthanides through the combined techniques of urea fractionated homogeneous precipitation and ion exchange [Abstract]. Instituto de Energia Atomica. 8(9), No. 395, 46 [in Portuguese]. Retrieved January 10, 2019, from https://inis.iaea.org.

21. Kim, J.K., Kim, U.S., Byeon, M.S., Kang, W.K., Hwang, K.T. \& Cho, W.S. (2011). Recovery of cerium from glass polishing slurry. J. Rare Earths. 29(11), 1075-1078. DOI: 10.1016/ S1002-0721(10)60601-1.

22. Qi, D. (2018). Hydrometallurgy of Rare Earths: Extraction and Separation. Cambridge, MA: Elsevier. Book chapter 7, 671-741.

23. Kondo, K., Matsuo, T. \& Matsumoto, M. (2015). Adsorptive separation of $\mathrm{La}, \mathrm{Ce}$ and Pr using microcapsules containing 2-ethylhexylphosphonic acid mono-2-ethylhexyl ester. Hydrometallurgy. 152, 204-213. DOI: 10.1016/j.hydromet.2015.01.004.

24. TEPA (Taiwan Environmental Protection Agency). (1998). Retrieved November 15, 2018, from https://www.epa.gov.tw/ niea/6362E9621F5D38DC. [in Chinese]

25. TEPA (Taiwan Environmental Protection Agency). (1992). Retrieved November 15, 2018, from https://www.epa.gov.tw/ niea/7FB27BAD6A4AC928. [in Chinese]

26. TEPA (Taiwan Environmental Protection Agency). (1993). Retrieved November 15, 2018, from https://www.epa.gov.tw/ niea/D650FF755904A079. [in Chinese]

27. Kuchma, M.H., Komanski, C.B., Colon, J., Teblum, A., Masunov, A.E., Alvarado, B., Babu, S., Seal, S., Summy, J. \& Baker, C.H. (2010). Phosphate ester hydrolysis of biologically relevant molecules by cerium oxide nanoparticles. NanomedNanotechnol. 6(6), 738-744. DOI: 10.1016/j.nano.2010.05.004.

28. Benavides, S. (2009). Corrosion control in the aerospace industry. Woodhead Publishing: Elsevier. 